\title{
Genetic Variability, Correlation and Path-Coefficient Studies in Litchi (Litchi chinensis Sonn.) for Plant Growth, Panicle and Yield Attributes
}

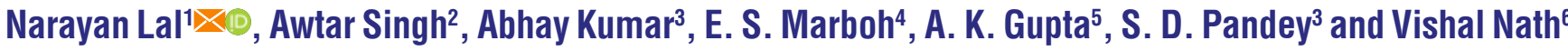 \\ ${ }^{1}$ ICAR-Indian Institute of Soil Science, Bhopal, Madhya Pradesh (462 038), India \\ ${ }^{2}$ ICAR-Indian Agricultural Research Institute, New Delhi (110 012), India \\ ${ }^{3}$ ICAR-National Research Centre on Litchi, Muzaffarpur, Bihar (842 002), India \\ ${ }^{4}$ ICAR-Central Citrus Research Institute, Regional Research Centre for Citrus, Biswanath Chariali, Assam (784 176), India \\ ${ }^{5}$ ICAR-Central Institute of Subtropical Horticultural, Lucknow, U.P. (226 101), India \\ ${ }^{6}$ ICAR- Indian Agricultural Research Institute, Hazaribagh, Jharkhand (825 405), India
}

Open Access

Corresponding $叉$ narayanlal.lal7@gmail.com

0000-0002-6715-3576

\section{ABSTRACT}

Studies were carried out in National Active Germplasm Site (NAGS) at ICAR-NRC on Litchi, Muzaffarpur, Bihar, India during 2018 and 2019 to find out the association between different characters and magnitude of association of different characters with yield $\left(\mathrm{kg} \mathrm{plant}^{-1}\right)$ in nine clones of litchi (Litchi chinensis Sonn.). Result revealed that genotypic coefficient were higher than their corresponding phenotypic ones implying an inherent relationship among them. The differences between genotypic and phenotypic coefficient of variation (PCV and GCV) were found narrow for all traits indicate least influence of environment on traits. Heritability was more than $80 \%$ for all the parameters studied except seed weight (34.90\%) and TSS (73.20\%). Correlation analysis quantifies only the degree of association between two characters and non-significant correlation coefficient value cannot be taken to imply absence of functional relationship between the two variables but path coefficient analysis reveals this by breaking the total correlation coefficient into components of direct and indirect effects. The number of leaflet, leaf length, leaf width, rachis length, petiole length, length of panicle, fruit weight, pulp weight, TSS, total sugar and seed weight exhibited positive correlation. Among the character studied, leaf length (1.646), TSS (0.975), length of panicle (0.900), petiole length (0.639), and number of fruit per panicle (0.601), seed weight $(0.465)$ and pulp weight $(0.370)$ recorded maximum positive direct effect towards yield at both the level. This study revealed that leaf length, panicle length, number of fruit per panicle and seed weight could form a selection criterion for yield improvement in litchi.

KEYWORDS: Litchi, clone, correlation coefficient, path analysis

Citation (VANCOUVER): Lal et al., Genetic Variability, Correlation and Path-Coefficient Studies in Litchi (Litchi chinensis Sonn.) for Plant growth, Panicle and Yield Attributes. International Journal of Bio-resource and Stress Management, 2022; 13(1), 29-36. HTTPS://DOI. ORG/10.23910/1.2022.2640.

Copyright: (c) $2022 \mathrm{Lal}$ et al. This is an open access article that permits unrestricted use, distribution and reproduction in any medium after the author(s) and source are credited.

Data Availability Statement: Legal restrictions are imposed on the public sharing of raw data. However, authors have full right to transfer or share the data in raw form upon request subject to either meeting the conditions of the original consents and the original research study. Further, access of data needs to meet whether the user complies with the ethical and legal obligations as data controllers to allow for secondary use of the data outside of the original study.

Conflict of interests: The authors have declared that no conflict of interest exists.

RECEIVED on $28^{\text {th }}$ September 2021 RECEIVED in revised form on $10^{\text {th }}$ January 2022 ACCEPTED in final form on $26^{\text {th }}$ January 2022 PUBLISHED on $31^{\text {st }}$ January 2022 


\section{INTRODUCTION}

T itchi (Litchi chinensis Sonn.) is evergreen fruit crop Whaving mycorrhizal association in the roots. It is highly specific to its climatic requirements, thus restricted to few states in India (Lal et al., 2017). Recently, it has been reported that litchi is performing well in the southern part of India but major litchi producing states are Bihar, Uttarakhand, West Bengal, Punjab, Uttar Pradesh, Jharkhand and Tripura. The prevailing temperature as well as phenol content and age of plants significantly affect flowering. The success of fruit set depends on male parents (Lal et al., 2019a,b), time of pollination (Lal et al., 2021a) and poor fruit retention is due to fruit drop (Chang et al., 2015). Litchi is a good source of vitamin C (Marboh et al., 2019). The litchi is highly cross pollinated crop (Srivastava et al., 2017) but self-pollination can not be ignored (Lal et al., 2021b). Litchi exhibited considerable genetic variation with respect to leaf colour, leaf size, fruit shape, fruit colour and texture, fragrance and flavour, size and form of the seed (Lal, 2018; Singh and Nath, 2012). The litchi fruit consists of about 55-85\% pulp, 6-27\% seed and 10-28 \% peel which varies depending upon cultivar and climatic conditions. Litchi is introduced crop. Litchi has narrow genetic base (Bajpai et al., 2016), still selection of clones from existing population under various environment condition can be done to widen diversity in litchi. The presence of significant variation in litchi can be used for identification and breeding purpose. Variability among the population of breeding material is the first pre-requisite for successful of any breeding programme. The litchi was introduced in India long back from China and variability is found in different corner of the litchi growing states. The high variability along with high heritability provides greater scope for further improvement in the traits. High values of heritability of the traits clarified that they were least affected by environmental modification and selection based on phenotypic performance would be reliable (Srivastava et al., 2014). Correlation studies help in finding out the degree of inter-relationship among various characters and in evolving selection criterion for improvement (Mir et al., 2006) and this study would help to identify the promising genetic material at early stage in the nursery. The leaf size is positively correlated with fruit size as it can be seen in Bedana and Gandaki Yogita in which leaf as well as fruit size is small. Similarly, small leaf size is positively correlated with dwarf stature of the plants. Path coefficient analysis provides a better index for selection than more correlation coefficient by separating the correlation coefficients of yield and its components into direct and indirect effects (Patel et al., 2015). It helps in determining the yield contributing traits and thus is useful in indirect selection. PCA and variability analysis revealed that fruit weight, pulp weight, peel weight, peel thickness, seed weight and seed size were important traits for identifying high-yielding genotypes (Marboh et al., 2018). Knowledge of correlations along with the understanding of the magnitude of path analysis (direct and indirect) of each component trait to the final make up of the fruit yield, the criteria formulated would be effective in selecting the genotypes and using themselves in the crop improvement programme. Therefore, the present study was carried out to find out all possible components characters for improvement of this crop through character association and path-coefficient analysis.

\section{MATERIALS AND METHODS}

$\mathrm{T}$ he present investigations were carried out available at ICAR-National Research Centre on Litchi, Muzaffarpur, Bihar, during the year 2018 and 2019 to describe various morphological characteristics of nine clones (IC - 0614728, IC - 0614729, IC - 0614730, IC - 0614731, IC - 0614732, IC - 0614733, IC - 0614735, IC - 0614737 and IC - 0614738) of litchi (Litchi chinensis Sonn.). Four uniform plants of each genotype (about 8 years old) were selected for the study and observations were recorded on the morphological characteristics of each clone. Leaf length, width, number of leaflets per leaf, rachis length and petiole length was studied by taking ten leaves and flushes randomly from each clone. Panicle length and width was recorded by measuring at maximum growth in ten panicles in each clone. Quality parameter (TSS, ascorbic acid and titratable acidity) were estimated from ten different fruits in each clone. The data recorded on above mentioned traits were statistically analyzed using OPSTAT package program. The genetic estimates, viz. phenotypic coefficient of variation (PCV) genotypic coefficient of variation $(\mathrm{GCV})$ and path analysis were computed. The correlation coefficient analysis among all the possible combination at phenotypic and genotypic level and estimates of direct and indirect effect of component characters on yield were estimated using standard methods.

\section{RESULTS AND DISCUSSION}

A nalysis of variance revealed that highly significant difference $(p=0.01)$ existed among clones for leaf, panicle and fruit traits studied. The estimates of range, population mean variance and genetic parameters, viz., phenotypic, genotypic and environmental coefficient of variation, heritability (broad sense) and genetic advance for leaf, panicle and fruit traits are presented in Table 1. The range of some economically important traits varied widely for fruit weight (16.38-24.68 g), pulp weight (12.23-14.56 g), and yield (3.86-8.75 kg plant $\left.{ }^{-1}\right)$ among studied clones. Marboh et al. (2018) reported fruit weight between $15.65-36.85 \mathrm{~g}$, pulp weight between $8.76-18.28 \mathrm{~g}$ and fruit yield between $37.29-73.51 \mathrm{~kg}$ in litchi genotypes. 
Fruit weight and yield depend on the age of plants. Also, large differences were observed for general coefficient of variation $(2.86-63.81 \%)$ for all the traits studied. The present variation in leaf, panicle and fruit traits reveals diversity of genotypes under study. Assessment of existing variability is a prerequisite in breeding program for selecting desirable clones. The range of variation, average mean performance, genotypic and phenotypic coefficients of variation, heritability and genetic advance (Table 1 ) revealed a wide range of variability for most characters studied. Phenotypic and genotypic coefficients of variation were high for seed weight (37.18 and $21.96 \%$ ), yield (27.39 and 26.42 $\%$ ) and length of panicle (23.67 and 23.44\%) and moderate to low for other traits. The high value of genotypic variance indicated more contribution of genetic components for the total observable variation. The estimates of GCV were lower in magnitude than PCV and the range was nominal indicating that there is lesser influence of environment on the traits studied and showed consistency in their expression irrespective of growing conditions. Therefore, traits with high genotypic variance could be considered and exploited for selection. The differences between genotypic and phenotypic coefficient of variation (PCV and $\mathrm{GCV}$ ) were found narrow for all traits indicate least influence of environment on traits. The high PCV and GCV have been found for seed weight (Attri et al., 1999; Patel et al.,

Table 1: Estimates of various genetic parameters of litchi genotypes

\begin{tabular}{lccccccccc}
\hline Traits & Range & Mean & SD & CV & GCV & PCV & HA & GA & GA \% \\
\hline Number of leaflet leaf ${ }^{-1}$ & $5.12-7.68$ & 6.85 & 0.97 & 14.14 & 14.11 & 14.22 & 98.45 & 1.97 & 28.83 \\
Leaf length (cm) & $8.86-15.68$ & 13.27 & 2.53 & 19.09 & 19.09 & 19.10 & 99.82 & 5.21 & 39.28 \\
Leaf width (cm) & $3.38-4.35$ & 3.98 & 0.33 & 8.37 & 8.34 & 8.44 & 97.65 & 0.68 & 16.97 \\
Rachis length (cm) & $6.27-11.12$ & 9.62 & 1.84 & 19.16 & 19.14 & 19.20 & 99.39 & 3.78 & 39.30 \\
Petiole length (cm) & $3.08-4.12$ & 3.82 & 0.38 & 9.89 & 9.78 & 10.12 & 93.48 & 0.74 & 19.48 \\
Length of panicle (cm) & $24.56-48.92$ & 42.64 & 10.03 & 23.52 & 23.44 & 23.67 & 98.07 & 20.39 & 47.82 \\
Number of fruit panicle ${ }^{-1}$ & $5.00-8.60$ & 7.02 & 1.31 & 26.74 & 18.57 & 19.00 & 95.45 & 2.62 & 37.37 \\
Fruit weight (g) & $16.38-24.68$ & 20.95 & 2.68 & 18.71 & 12.43 & 13.52 & 84.44 & 4.93 & 23.52 \\
Pulp weight (g) & $12.23-14.56$ & 13.52 & 0.87 & 2.86 & 6.22 & 6.86 & 82.29 & 1.57 & 11.62 \\
Seed weight (g) & $1.85-4.56$ & 3.73 & 1.04 & 14.47 & 21.96 & 37.18 & 34.90 & 1.00 & 26.73 \\
TSS (Brix) & $17.86-21.47$ & 20.10 & 1.28 & 6.26 & 5.99 & 7.01 & 73.20 & 2.12 & 10.56 \\
Ascorbic acid (mg 100 g-1) & $24.56-35.68$ & 28.00 & 3.85 & 6.35 & 13.68 & 13.94 & 96.28 & 7.74 & 27.65 \\
Total sugar (\%) & $10.12-14.25$ & 12.26 & 1.59 & 13.77 & 12.50 & 13.95 & 80.24 & 2.83 & 23.06 \\
Yield (kg) & $3.86-8.75$ & 7.14 & 1.91 & 63.81 & 26.42 & 27.39 & 93.02 & 3.75 & 52.48 \\
\hline
\end{tabular}

2015). Gupta and Kour (2019) reported high GCV and PCV for fruit yield per plant in guava. Result revealed that these traits offer good scope for selection in litchi. The higher values of both PCV and GCV for various traits like length of panicle, seed weight and yield indicate that greater improvement can be expected through selection based on these characters. The focus should be given on length and girth of panicle (Lal et al., 2020), fruit size (Singh and Nath, 2012), higher pulp content and regular bearing (Lal et al., 2019c) for improvement in litchi. Low estimates of $\mathrm{PCV}$ and GCV for particular traits indicate that selection based on the traits would not be much effective. Closeness between PCV and GCV for some characters indicates that the phenotypic expression of all the genotypes is mostly under the genetic control and comparatively stable to environmental influences.

Further, contribution of these traits to the total variability across the genotypes indicated the greater contribution of

additive gene action on the expression of these traits (Verma et al., 2014). High PCV and GCV for yield and panicle length pointed towards importance of these traits in the total variability. The higher coefficients of variation of any traits offer a good opportunity for further improvement through selection. The nature as well as extent of genetic variability in the plant species is very important criteria in formulating an efficient breeding programme. Similarly, knowledge of phenotypic coefficient of variation (PCV) and genotypic coefficient of variation $(\mathrm{GCV})$ is much helpful in predicting the amount of variation present in a given genetic stock. Therefore, these traits could be considered and exploited for selection purpose.

However, the genotypic coefficient of variation does not offer full scope to estimate the variation that is heritable in nature and therefore, estimation of heritability becomes necessary. The reliability of phenotypic value is predicted by the estimates of heritability. Since most of the desired 
traits like yield are quantitative in nature, complex in their inheritance and greatly influenced by environmental conditions, heritability can play a useful role to estimate the scope of improvement by selection. This indicates that selection will be effective for selecting genotypes having traits with high heritability which are useful in predicting the expected progress to be achieved. This is because there would be a close correspondence between the genotypes and the phenotype due to smaller environmental effects. Heritability estimates revealed that all the characters under study ranged from 99.82 in leaf length to 34.90 in seed weight (Table 1). Heritability in broad sense was more than $80 \%$ for all the parameters except seed weight (34.90\%) and TSS (73.20\%). The high heritability indicates that the traits under study had great scope for genetic improvement. Rajan et al. (2009) also observed high heritability for different characters in several fruit crops. The scope of crop improvement through selection is limited with low to moderate heritability. Hence, computation of heritability alone will not be sufficient to bring about an efficient improvement in fruit traits unless there is a higher genetic gain, involving additive gene action which can be achieved through selection. Estimated heritability associated with genetic advance is more reliable than heritability alone for predicting the impact of selection. Genetic advance is the indicator of the progress that can be expected as a result of exercising selection on the pertinent population. Genetic advance depends on genetic variability and heritability. Genetic advance as per cent of mean varied from 10.56 (TSS) to 52.48 (Yield). Higher percentage of genetic advance was also observed in panicle length (47.82) and rachis length 39.30). A higher heritability along with high genetic advance provides the most effective criteria for selection in crop improvement (Johnson et al., 1955). In the present study, higher heritability estimates accompanied with greater genetic advance were observed for all the parameters except pulp weight and TSS indicating that these characters are exhibiting additive gene action and phenotypic selection may be more fruitful for all these traits. The higher values of heritability of traits revealed that they are least influenced by environmental factor and selection based on phenotypic performance would be reliable. Similar findings were also reported by other workers (Srivastava et al., 2014) who reported high heritability with high genetic gain for different attributes in other fruits crops.

In a majority of the characters studied, genotypic correlation coefficient was found to be higher in magnitude than

Table 2: Genotypic (G), Phenotypic (P) and Environmental (E) correlation coefficients of some important characters in litchi on yield

\begin{tabular}{|c|c|c|c|c|c|c|c|}
\hline Characters & & $\begin{array}{l}\text { No. of } \\
\text { leaflet }\end{array}$ & $\begin{array}{l}\text { Leaf length } \\
(\mathrm{cm})\end{array}$ & $\begin{array}{l}\text { Leaf width } \\
(\mathrm{cm})\end{array}$ & $\begin{array}{c}\text { Rachis } \\
\text { length }(\mathrm{cm})\end{array}$ & $\begin{array}{c}\text { Petiole } \\
\text { length }(\mathrm{cm})\end{array}$ & $\begin{array}{c}\text { Length of } \\
\text { panicle }(\mathrm{cm})\end{array}$ \\
\hline \multirow[t]{3}{*}{ Leaf length $(\mathrm{cm})$} & G & $0.963^{*+*}$ & & & & & \\
\hline & $\mathrm{P}$ & $0.955^{* * *}$ & & & & & \\
\hline & $\mathrm{E}$ & $0.118^{\mathrm{NS}}$ & & & & & \\
\hline \multirow[t]{3}{*}{ Leaf width $(\mathrm{cm})$} & G & $0.943^{* *}$ & $0.968^{*+*}$ & & & & \\
\hline & $\mathrm{P}$ & $0.918^{* * *}$ & $0.956^{* *}$ & & & & \\
\hline & $\mathrm{E}$ & $-0.384^{*}$ & $0.009^{\mathrm{NS}}$ & & & & \\
\hline \multirow[t]{3}{*}{ Rachis length (cm } & G & 0.956 & $0.947^{* *}$ & $0.951^{\text {*it }}$ & & & \\
\hline & $\mathrm{P}$ & $0.942^{* *}$ & $0.944^{* *}$ & $0.936^{* *}$ & & & \\
\hline & $\mathrm{E}$ & $-0.348^{\mathrm{NS}}$ & $0.314^{\mathrm{NS}}$ & $-0.096^{\mathrm{NS}}$ & & & \\
\hline \multirow[t]{3}{*}{ Petiole length $(\mathrm{cm})$} & G & $0.968^{* * *}$ & $0.976^{* *}$ & $0.945^{* *}$ & $0.975^{* *}$ & & \\
\hline & $\mathrm{P}$ & $0.935^{* *}$ & $0.944^{* *}$ & $0.897^{* *}$ & $0.937^{* *}$ & & \\
\hline & $\mathrm{E}$ & $0.197^{\mathrm{NS}}$ & $0.133^{\mathrm{NS}}$ & $-0.143^{\mathrm{NS}}$ & $-0.183^{\mathrm{NS}}$ & & \\
\hline \multirow[t]{3}{*}{ Length of panicle $(\mathrm{cm})$} & G & $0.970^{* *}$ & $0.969^{* *}$ & $0.962^{* *}$ & $0.995^{* *}$ & $0.987^{* *}$ & \\
\hline & $\mathrm{P}$ & $0.961^{* * *}$ & $0.961^{* *}$ & $0.932^{*+*}$ & $0.983^{* *+}$ & $0.959^{* * *}$ & \\
\hline & $\mathrm{E}$ & $0.475^{* *}$ & $0.271^{\mathrm{NS}}$ & $-0.468^{*}$ & $0.116^{\mathrm{NS}}$ & $0.410^{*}$ & \\
\hline \multirow[t]{3}{*}{ Number of fruit/panicle } & G & $-0.160^{\mathrm{NS}}$ & $-0.093^{\mathrm{NS}}$ & $-0.013^{\mathrm{NS}}$ & $-0.057^{\mathrm{NS}}$ & $-0.212^{\mathrm{NS}}$ & $-0.098^{\mathrm{NS}}$ \\
\hline & $\mathrm{P}$ & $-0.144^{\mathrm{NS}}$ & $-0.089^{\mathrm{NS}}$ & $-0.011^{\mathrm{NS}}$ & $-0.056^{\mathrm{NS}}$ & $-0.205^{\mathrm{NS}}$ & $-0.090^{\mathrm{NS}}$ \\
\hline & $\mathrm{E}$ & $0.391^{*}$ & $0.196^{\mathrm{NS}}$ & $0.049^{\mathrm{NS}}$ & $-0.058^{\mathrm{NS}}$ & $-0.102^{\mathrm{NS}}$ & $0.143^{\mathrm{NS}}$ \\
\hline
\end{tabular}




\begin{tabular}{|c|c|c|c|c|c|c|c|c|}
\hline & & $\begin{array}{l}\text { No. of } \\
\text { leaflet }\end{array}$ & $\begin{array}{l}\text { Leaf length } \\
(\mathrm{cm})\end{array}$ & $\begin{array}{l}\text { Leaf width } \\
(\mathrm{cm})\end{array}$ & $\begin{array}{c}\text { Rachis } \\
\text { length }(\mathrm{cm})\end{array}$ & $\begin{array}{c}\text { Petiole } \\
\text { length }(\mathrm{cm})\end{array}$ & $\begin{array}{c}\text { Length of } \\
\text { panicle }(\mathrm{cm})\end{array}$ & $\begin{array}{l}\text { No. of fruit } \\
\text { panicle }^{-1}\end{array}$ \\
\hline \multirow[t]{3}{*}{ Fruit weight (g) } & G & $0.909^{* * *}$ & $0.864^{* * *}$ & $0.799^{* * *}$ & $0.877^{\text {*** }}$ & $0.938^{* * *}$ & $0.903^{* * *}$ & $-0.551^{* *}$ \\
\hline & $\mathrm{P}$ & $0.808^{* * *}$ & $0.794^{* * *}$ & $0.750^{* * *}$ & $0.805^{* * *}$ & $0.825^{* * *}$ & $0.815^{* *}$ & $-0.549^{* * *}$ \\
\hline & $\mathrm{E}$ & $-0.425^{*}$ & $0.031^{\mathrm{NS}}$ & $0.401^{*}$ & $0.038^{\mathrm{NS}}$ & $-0.083^{\mathrm{NS}}$ & $-0.129^{\mathrm{NS}}$ & $-0.645^{* * *}$ \\
\hline \multirow[t]{3}{*}{ Pulp weight (g) } & G & $0.860^{* * *}$ & $0.815^{\text {wat }}$ & $0.715^{* * *}$ & $0.782^{* * *}$ & $0.888^{* * *}$ & $0.839^{* * *}$ & $-0.640^{* * *}$ \\
\hline & $\mathrm{P}$ & $0.748^{* * *}$ & $0.733^{* * *}$ & $0.659^{* * *}$ & $0.710^{* * *}$ & $0.745^{* * *}$ & $0.739^{* * *}$ & $-0.613^{* * *}$ \\
\hline & $\mathrm{E}$ & $-0.511^{* * *}$ & $-0.319^{\mathrm{NS}}$ & $0.279^{\mathrm{NS}}$ & $0.069^{\mathrm{NS}}$ & $-0.312^{\mathrm{NS}}$ & $-0.243^{\mathrm{NS}}$ & $-0.510^{m *}$ \\
\hline \multirow[t]{3}{*}{ TSS (Brix) } & G & $0.988^{* * *}$ & $0.940^{* * *}$ & $0.974^{* * *}$ & $0.917^{* * *}$ & $0.927^{* * *}$ & $0.940^{* *+}$ & $-0.157^{\mathrm{NS}}$ \\
\hline & $\mathrm{P}$ & $0.846^{* * *}$ & $0.803^{* * *}$ & $0.817^{* * *}$ & $0.780^{* * *}$ & $0.854^{* * *}$ & $0.794^{* * *}$ & $-0.142^{\mathrm{NS}}$ \\
\hline & $\mathrm{E}$ & $0.118^{\mathrm{NS}}$ & $-0.055^{\mathrm{NS}}$ & $-0.076^{\mathrm{NS}}$ & $-0.038^{\mathrm{NS}}$ & $0.658^{* * *}$ & $-0.027^{\mathrm{NS}}$ & $-0.100^{\mathrm{NS}}$ \\
\hline \multirow{3}{*}{$\begin{array}{l}\text { Ascorbic acid } \\
(\mathrm{mg} / 100 \mathrm{~g})\end{array}$} & G & $-0.892^{* * *}$ & $-0.882^{* * *}$ & $-0.924^{* * *}$ & $-0.958^{* * *}$ & $-0.922^{* * *}$ & $-0.932^{* * *}$ & $0.221^{\mathrm{NS}}$ \\
\hline & $\mathrm{P}$ & $-0.868^{* * *}$ & $-0.862^{* *}$ & $-0.889^{* *}$ & $-0.938^{* * *}$ & $-0.879^{* * *}$ & $-0.915^{* * *}$ & $0.215^{\mathrm{NS}}$ \\
\hline & $\mathrm{E}$ & $-0.015^{\mathrm{NS}}$ & $0.338^{\mathrm{NS}}$ & $0.236^{\mathrm{NS}}$ & $-0.098^{\mathrm{NS}}$ & $-0.083^{\mathrm{NS}}$ & $-0.347^{\mathrm{NS}}$ & $0.085^{\mathrm{NS}}$ \\
\hline \multirow[t]{3}{*}{ Total sugar (\%) } & G & $0.492^{* * *}$ & $0.469^{*}$ & $0.666^{* * *}$ & $0.603^{* * *}$ & $0.589^{* * *}$ & $0.563^{* *}$ & $-0.005^{\mathrm{NS}}$ \\
\hline & $\mathrm{P}$ & $0.445^{*}$ & $0.422^{*}$ & $0.569^{* * *}$ & $0.544^{* * *}$ & $0.492^{* * *}$ & $0.519^{* * *}$ & $0.002^{\mathrm{NS}}$ \\
\hline & $\mathrm{E}$ & $0.133^{\mathrm{NS}}$ & $0.088^{\mathrm{NS}}$ & $-0.292^{\mathrm{NS}}$ & $0.152^{\mathrm{NS}}$ & $-0.157^{\mathrm{NS}}$ & $0.317^{\mathrm{NS}}$ & $0.064^{\mathrm{NS}}$ \\
\hline \multirow[t]{3}{*}{ Seed weight (g) } & G & $1.253^{* * *}$ & $1.225^{* * *}$ & $1.178^{* * *}$ & $1.236^{* *}$ & $1.284^{* * *}$ & $1.281^{* *}$ & $-0.059^{\mathrm{NS}}$ \\
\hline & $\mathrm{P}$ & $0.746^{* *}$ & $0.723^{* * *}$ & $0.739^{* * *}$ & $0.743^{* *}$ & $0.656^{* *}$ & $0.710^{* * *}$ & $-0.006^{\mathrm{NS}}$ \\
\hline & $\mathrm{E}$ & $0.113^{\mathrm{NS}}$ & $-0.011^{\mathrm{NS}}$ & $0.417^{*}$ & $0.236^{\mathrm{NS}}$ & $-0.376^{*}$ & $-0.351^{\mathrm{NS}}$ & $0.162^{\mathrm{NS}}$ \\
\hline \multirow[t]{3}{*}{ Yield } & G & $0.878^{* * *}$ & $0.945^{* *}$ & $0.915^{* * *}$ & $0.948^{* *+}$ & $0.907^{\text {akt }}$ & $0.945^{* * *}$ & $0.176^{\mathrm{NS}}$ \\
\hline & $\mathrm{P}$ & $0.849^{* * *}$ & $0.905^{* * *}$ & $0.877^{\prime * *}$ & $0.908^{* * *}$ & $0.849^{* * *}$ & $0.896^{* * *}$ & $0.168^{\mathrm{NS}}$ \\
\hline & $\mathrm{E}$ & $0.245^{\mathrm{NS}}$ & $-0.432^{*}$ & $0.127^{\mathrm{NS}}$ & $-0.165^{\mathrm{NS}}$ & $0.047^{\mathrm{NS}}$ & $-0.190^{\mathrm{NS}}$ & $0.029^{\mathrm{NS}}$ \\
\hline
\end{tabular}

Table 2: Continue...

\begin{tabular}{|c|c|c|c|c|c|c|c|}
\hline & & $\begin{array}{c}\text { Fruit weight } \\
\text { (g) }\end{array}$ & $\begin{array}{l}\text { Pulp } \\
\text { weight (g) }\end{array}$ & $\begin{array}{l}\text { TSS } \\
\text { (Brix) }\end{array}$ & 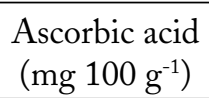 & $\begin{array}{c}\text { Total } \\
\text { sugar (\%) }\end{array}$ & $\begin{array}{l}\text { Seed weight } \\
\text { (g) }\end{array}$ \\
\hline \multirow[t]{3}{*}{ Pulp weight (g) } & G & $1.006^{* *}$ & & & & & \\
\hline & $\mathrm{P}$ & $0.921^{* * *}$ & & & & & \\
\hline & $\mathrm{E}$ & $0.501^{* *}$ & & & & & \\
\hline \multirow[t]{3}{*}{ TSS (Brix) } & G & $0.854^{* *}$ & $0.795^{* * *}$ & & & & \\
\hline & $\mathrm{P}$ & $0.606^{*}$ & $0.564^{* *}$ & & & & \\
\hline & $\mathrm{E}$ & $-0.321^{\mathrm{NS}}$ & $-0.242^{\mathrm{NS}}$ & & & & \\
\hline \multirow[t]{3}{*}{ Ascorbic acid (mg/100g) } & G & $-0.897^{* * *}$ & $-0.790^{* * *}$ & $-0.889^{* * *}$ & & & \\
\hline & $\mathrm{P}$ & $-0.816^{* *}$ & $-0.706^{* *}$ & $-0.755^{* *}$ & & & \\
\hline & $\mathrm{E}$ & $-0.087^{\mathrm{NS}}$ & $-0.037^{\mathrm{NS}}$ & $-0.085^{\mathrm{NS}}$ & & & \\
\hline \multirow[t]{3}{*}{ Total sugar (\%) } & G & $0.453^{*}$ & $0.301^{\mathrm{NS}}$ & $0.682^{* *}$ & $-0.686^{* *}$ & & \\
\hline & $\mathrm{P}$ & $0.345^{\mathrm{NS}}$ & $0.200^{\mathrm{NS}}$ & $0.522^{* *}$ & $-0.602^{* *}$ & & \\
\hline & $\mathrm{E}$ & $-0.160^{\mathrm{NS}}$ & $-0.237^{\mathrm{NS}}$ & $-0.001^{\mathrm{NS}}$ & $0.018^{\mathrm{NS}}$ & & \\
\hline \multirow[t]{3}{*}{ Seed weight (g) } & G & $1.095^{* *}$ & $1.023^{* * *}$ & $1.264^{* *}$ & $-1.161^{* *}$ & $0.669^{* *}$ & \\
\hline & $\mathrm{P}$ & $0.580^{* *}$ & $0.513^{* *}$ & $0.594^{* *}$ & $-0.637^{* *}$ & $0.364^{\mathrm{NS}}$ & \\
\hline & $\mathrm{E}$ & $-0.044^{\mathrm{NS}}$ & $-0.103^{\mathrm{NS}}$ & $-0.107^{\mathrm{NS}}$ & $0.230^{\mathrm{NS}}$ & $0.029^{\mathrm{NS}}$ & \\
\hline
\end{tabular}




\begin{tabular}{lccccccc}
\hline & & $\begin{array}{c}\text { Fruit weight } \\
(\mathrm{g})\end{array}$ & $\begin{array}{c}\text { Pulp } \\
\text { weight }(\mathrm{g})\end{array}$ & $\begin{array}{c}\text { TSS } \\
(\text { Brix })\end{array}$ & $\begin{array}{c}\text { Ascorbic acid } \\
(\mathrm{mg} / 100 \mathrm{~g})\end{array}$ & $\begin{array}{c}\text { Total } \\
\text { sugar }(\%)\end{array}$ & $\begin{array}{c}\text { Seed weight } \\
(\mathrm{g})\end{array}$ \\
\hline Yield & $\mathrm{G}$ & $0.748^{* *}$ & $0.651^{* *}$ & $0.771^{* *}$ & $-0.834^{* *}$ & $0.446^{*}$ & $1.117^{* *}$ \\
& $\mathrm{P}$ & $0.636^{* *}$ & $0.553^{* *}$ & $0.656^{* *}$ & $-0.793^{* *}$ & $0.369^{*}$ & $0.749^{* *}$ \\
& $\mathrm{E}$ & $-0.262^{\mathrm{NS}}$ & $-0.153^{\mathrm{NS}}$ & $0.140^{\mathrm{NS}}$ & $-0.069^{\mathrm{NS}}$ & $-0.134^{\mathrm{NS}}$ & $0.527^{* *}$ \\
\hline
\end{tabular}

phenotypic correlation coefficient, indicating strong inherent association among various characters (Table 2). Yield exhibited positive and significant association with number of leaflet, leaf length, lead width, rachis length, petiole length, length of panicle, fruit weight, pulp weight, TSS total sugar, seed weight but negative association with ascorbic acid content in pulp. Fruit weight was positively correlated with number of leaf, leaf length, leaf width, rachis length, petiole length, panicle length and negatively correlated with number of fruit/panicle. TSS was positively correlated with number of leaf, leaf length, leaf width, rachis length, petiole length, panicle length, fruit weight and pulp weight. Path coefficient analysis was performed to assess direct and indirect effects of different

Table 3: Direct (Diagonal) and indirect effect of important characters on yield in litchi

\begin{tabular}{|c|c|c|c|c|c|c|c|c|}
\hline Character & & $\begin{array}{l}\text { No. of } \\
\text { leaflet }\end{array}$ & $\begin{array}{l}\text { Leaf length } \\
(\mathrm{cm})\end{array}$ & $\begin{array}{l}\text { Leaf width } \\
\quad(\mathrm{cm})\end{array}$ & $\begin{array}{c}\text { Rachis } \\
\text { length }(\mathrm{cm})\end{array}$ & $\begin{array}{c}\text { Petiole } \\
\text { length }(\mathrm{cm})\end{array}$ & $\begin{array}{c}\text { Length of } \\
\text { panicle }(\mathrm{cm})\end{array}$ & $\begin{array}{l}\text { No. of fruit } \\
\text { panicle }^{-1}\end{array}$ \\
\hline \multirow{2}{*}{$\begin{array}{l}\text { Number of } \\
\text { leaflet }\end{array}$} & $\mathrm{G}$ & -1.646 & 1.584 & -2.031 & -0.970 & 0.619 & 0.873 & -0.096 \\
\hline & $\mathrm{P}$ & -0.083 & 0.523 & -0.152 & 0.073 & 0.682 & -0.397 & -0.059 \\
\hline \multirow{2}{*}{$\begin{array}{l}\text { Leaf length } \\
(\mathrm{cm})\end{array}$} & $\mathrm{G}$ & -1.584 & 1.646 & -2.085 & -0.961 & 0.624 & 0.872 & -0.056 \\
\hline & $\mathrm{P}$ & -0.079 & 0.548 & -0.159 & 0.073 & 0.688 & -0.397 & -0.036 \\
\hline \multirow{2}{*}{$\begin{array}{l}\text { Leaf width } \\
(\mathrm{cm})\end{array}$} & G & -1.553 & 1.594 & -2.153 & -0.965 & 0.604 & 0.866 & -0.008 \\
\hline & $\mathrm{P}$ & -0.076 & 0.524 & -0.166 & 0.072 & 0.654 & -0.385 & -0.004 \\
\hline \multirow{2}{*}{$\begin{array}{l}\text { Rachis length } \\
(\mathrm{cm})\end{array}$} & G & -1.573 & 1.558 & -2.048 & -1.015 & 0.624 & 0.895 & -0.034 \\
\hline & $\mathrm{P}$ & -0.078 & 0.517 & -0.155 & 0.077 & 0.683 & -0.406 & -0.023 \\
\hline \multirow{2}{*}{$\begin{array}{l}\text { Petiole length } \\
(\mathrm{cm})\end{array}$} & G & -1.593 & 1.605 & -2.034 & -0.990 & 0.639 & 0.888 & -0.127 \\
\hline & $\mathrm{P}$ & -0.077 & 0.517 & -0.149 & 0.072 & 0.729 & -0.396 & -0.084 \\
\hline \multirow{2}{*}{$\begin{array}{l}\text { Length of } \\
\text { panicle }(\mathrm{cm})\end{array}$} & $\mathrm{G}$ & -1.596 & 1.595 & -2.072 & -1.009 & 0.631 & 0.900 & -0.059 \\
\hline & $\mathrm{P}$ & -0.079 & 0.526 & -0.155 & 0.076 & 0.699 & -0.413 & -0.037 \\
\hline \multirow{2}{*}{$\begin{array}{l}\text { Number of } \\
\text { fruit panicle }\end{array}$} & G & 0.263 & -0.153 & 0.028 & 0.057 & -0.135 & -0.088 & 0.601 \\
\hline & $\mathrm{P}$ & 0.012 & -0.049 & 0.002 & -0.004 & -0.150 & 0.037 & 0.407 \\
\hline \multirow{2}{*}{$\begin{array}{l}\text { Fruit weight } \\
\text { (g) }\end{array}$} & G & -1.496 & 1.422 & -1.720 & -0.890 & 0.600 & 0.813 & -0.331 \\
\hline & $\mathrm{P}$ & -0.067 & 0.435 & -0.124 & 0.062 & 0.601 & -0.336 & -0.224 \\
\hline \multirow{2}{*}{$\begin{array}{l}\text { Pulp weight } \\
\text { (g) }\end{array}$} & G & -1.416 & 1.342 & -1.539 & -0.794 & 0.568 & 0.755 & -0.385 \\
\hline & $\mathrm{P}$ & -0.062 & 0.402 & -0.109 & 0.055 & 0.543 & -0.305 & -0.250 \\
\hline \multirow[t]{2}{*}{ TSS (Brix) } & G & -1.626 & 1.547 & -2.096 & -0.930 & 0.593 & 0.846 & -0.094 \\
\hline & $\mathrm{P}$ & -0.070 & 0.440 & -0.136 & 0.060 & 0.623 & -0.328 & -0.058 \\
\hline \multirow{2}{*}{$\begin{array}{l}\text { Ascorbic acid } \\
\left(\mathrm{mg} 100 \mathrm{~g}^{-1}\right)\end{array}$} & G & 1.467 & -1.451 & 1.989 & 0.972 & -0.589 & -0.839 & 0.133 \\
\hline & $\mathrm{P}$ & 0.072 & -0.472 & 0.147 & -0.072 & -0.641 & 0.378 & 0.088 \\
\hline \multirow{2}{*}{$\begin{array}{l}\text { Total sugar } \\
(\%)\end{array}$} & $\mathrm{G}$ & -0.810 & 0.773 & -1.433 & -0.612 & 0.376 & 0.507 & -0.003 \\
\hline & $\mathrm{P}$ & -0.037 & 0.231 & -0.094 & 0.042 & 0.359 & -0.214 & 0.001 \\
\hline \multirow{2}{*}{$\begin{array}{l}\text { Seed weight } \\
\text { (g) }\end{array}$} & G & -2.062 & 2.016 & -2.535 & -1.255 & 0.821 & 1.152 & -0.035 \\
\hline & $\mathrm{P}$ & -0.062 & 0.396 & -0.123 & 0.057 & 0.478 & -0.293 & -0.003 \\
\hline
\end{tabular}




\begin{tabular}{|c|c|c|c|c|c|c|c|}
\hline Character & & $\begin{array}{l}\text { Fruit weight } \\
\text { (g) }\end{array}$ & $\begin{array}{l}\text { Pulp weight } \\
\text { (g) }\end{array}$ & $\begin{array}{l}\text { TSS } \\
\text { (Brix) }\end{array}$ & 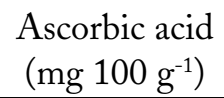 & $\begin{array}{l}\text { Total sugar } \\
\text { (\%) }\end{array}$ & $\begin{array}{l}\text { Seed weight } \\
\text { (g) }\end{array}$ \\
\hline \multirow[t]{2}{*}{ Number of leaflet } & G & -0.594 & 0.318 & 0.963 & 1.375 & -0.100 & 0.582 \\
\hline & $\mathrm{P}$ & -0.101 & 0.141 & -0.246 & 0.326 & -0.032 & 0.174 \\
\hline \multirow[t]{2}{*}{ Leaf length $(\mathrm{cm})$} & G & -0.565 & 0.302 & 0.917 & 1.360 & -0.095 & 0.569 \\
\hline & $\mathrm{P}$ & -0.099 & 0.138 & -0.233 & 0.323 & -0.030 & 0.168 \\
\hline \multirow[t]{2}{*}{ Leaf width $(\mathrm{cm})$} & G & -0.522 & 0.265 & 0.949 & 1.425 & -0.135 & 0.547 \\
\hline & $\mathrm{P}$ & -0.094 & 0.124 & -0.238 & 0.333 & -0.040 & 0.172 \\
\hline \multirow[t]{2}{*}{ Rachis length $(\mathrm{cm})$} & G & -0.573 & 0.290 & 0.894 & 1.477 & -0.122 & 0.575 \\
\hline & $\mathrm{P}$ & -0.101 & 0.134 & -0.227 & 0.352 & -0.039 & 0.173 \\
\hline \multirow[t]{2}{*}{ Petiole length $(\mathrm{cm})$} & G & -0.613 & 0.329 & 0.904 & 1.422 & -0.119 & 0.596 \\
\hline & $\mathrm{P}$ & -0.103 & 0.140 & -0.248 & 0.330 & -0.035 & 0.153 \\
\hline \multirow[t]{2}{*}{ Length of panicle $(\mathrm{cm})$} & G & -0.591 & 0.310 & 0.916 & 1.438 & -0.114 & 0.595 \\
\hline & $\mathrm{P}$ & -0.102 & 0.139 & -0.231 & 0.343 & -0.037 & 0.165 \\
\hline \multirow[t]{2}{*}{ Number of fruit panicle ${ }^{-1}$} & G & 0.360 & -0.237 & -0.153 & -0.341 & 0.001 & -0.027 \\
\hline & $\mathrm{P}$ & 0.069 & -0.116 & 0.041 & -0.081 & 0.000 & -0.001 \\
\hline \multirow[t]{2}{*}{ Fruit weight (g) } & G & -0.654 & 0.372 & 0.833 & 1.384 & -0.092 & 0.509 \\
\hline & $\mathrm{P}$ & -0.125 & 0.174 & -0.176 & 0.306 & -0.025 & 0.135 \\
\hline \multirow[t]{2}{*}{ Pulp weight (g) } & G & -0.657 & 0.370 & 0.775 & 1.219 & -0.061 & 0.475 \\
\hline & $\mathrm{P}$ & -0.115 & 0.188 & -0.164 & 0.265 & -0.014 & 0.119 \\
\hline \multirow[t]{2}{*}{ TSS (Brix) } & G & -0.558 & 0.294 & 0.975 & 1.371 & -0.138 & 0.588 \\
\hline & $\mathrm{P}$ & -0.076 & 0.106 & -0.291 & 0.283 & -0.037 & 0.138 \\
\hline \multirow[t]{2}{*}{ Ascorbic acid (mg $\left.100 \mathrm{~g}^{-1}\right)$} & G & 0.587 & -0.292 & -0.867 & -1.542 & 0.139 & -0.539 \\
\hline & $\mathrm{P}$ & 0.102 & -0.133 & 0.219 & -0.375 & 0.043 & -0.148 \\
\hline \multirow[t]{2}{*}{ Total sugar (\%) } & G & -0.296 & 0.112 & 0.665 & 1.059 & -0.202 & 0.311 \\
\hline & $\mathrm{P}$ & -0.043 & 0.038 & -0.152 & 0.226 & -0.071 & 0.085 \\
\hline \multirow[t]{2}{*}{ Seed weight (g) } & G & -0.715 & 0.379 & 1.233 & 1.790 & -0.135 & 0.465 \\
\hline & $\mathrm{P}$ & -0.073 & 0.097 & -0.173 & 0.239 & -0.026 & 0.233 \\
\hline
\end{tabular}

G: Genotype; Residual effect: 0.066, P: Phenotype; Residual effect: 0.053

characters on yield (Table 3). Correlation analysis quantify only the degree of association between two characters, it does not provide reason for such association. Thus, nonsignificant correlation coefficient value cannot be taken to imply absence of functional relationship between the two variables. Path coefficient analysis reveals this by breaking the total correlation coefficient into components of direct and indirect effects. Leaf length (1.646) had a very high positive direct genotypic effect on yield followed by TSS (0.975), length of panicle (0.900), petiole length (0.639), and number of fruit per panicle (0.601), seed weight (0.465) and pulp weight (0.370). Petiole length, panicle length, pulp weight, TSS, ascorbic acid and seed weight had a positive indirect effect and leaf width, rachis length,, number of fruit per panicle, fruit weight, and total sugar had negative indirect effect on yield. These results are in consonance with those of Baiyer and Ortiz (1995) who reported that yield was more closely related to number of fruits plant ${ }^{-1}$ in pomegranate and Banana, respectively. Direct positive effect of fruit weight on yield in pomegranate and Ber has been reported by Mir et al. (2006). The traits of number of leaflet, leaf width, rachis length, fruit weight, ascorbic acid and total sugar imparted negative direct effect on yield. Residual effect at the genotypic level was found to be slightly more than at the phenotypic level. Low magnitude of residual effect at phenotypic level indicated enough character included in the present study. 


\section{CONCLUSION}

$\mathrm{T}$ he higher values of PCV and GCV for seed weight and length panicle indicated that further improvement can be achieved through selection based on these characters. High heritability with high genetic advance indicated that selection of this character would be more effective. Leaf length, TSS, length of panicle, petiole length and number of fruit per panicle, seed weight and pulp weight exhibited direct positive effect on yield and these traits must be given due importance while selecting a genotype.

\section{REFERENCES}

Attri, B.L., Sharma, T.V.R.S., Singh, D.B., Nagesh, P., 1999. Genetic variability and correlation studies in mango collections of south Andaman. Indian Journal of Horticulture 56(2), 144-148.

Baiyeri, K.P., Ortiz, R., 1995. Path analysis of yield in dessert banana. Musa Africa 8, 3-5.

Bajpai, A., Muthukumar, M., Singh, A., Nath, V., Ravishnkar, H., 2016. Narrow genetic base of Indian litchi (Litchi chinensis) cultivars based on molecular markers. Indian Journal of Agricultural Sciences 86(4), 448-455.

Chang, J.Y., Chang, Y.A., Tang, L., Chang, J.W., 2015. Characterization of generative development in early maturing litchi 'Early Big', a novel cultivar in Taiwan. Fruits 70, 289-296.

Gupta, N., Kour, A., 2019. Genetic parameters, character association and path analysis for fruit yield and its component characters in guava (Psidium guajava L.). Electronic Journal of Plant Breeding 10(1), 256-263.

Johnson, H.N., Robinson, H.F., Comstock, R.E., 1955. Estimates of genetic and environmental variability in soybean. Agronomy Journal 47, 314-318.

Lal, N., 2018. Genetic studies of litchi germplasm, Ph.D. Thesis submitted to JNKVV Jabalpur, MP.

Lal, N., Gupta, A.K., Kushwah, N.S., Nath, V., 2017. Sapindaceous Fruits: In: Peter, K.V. (Ed.), Horticultural Crops of High Nutritive Values. Brillion Publishing, New Delhi.

Lal, N., Gupta, A.K., Marboh, E.S., Kumar, A., Nath, V., 2021b. Effect of mode of pollination on fruit set and fruit characteristics in litchi. Erwerbs-Obstbau 63, 227-232.

Lal, N., Gupta, A.K., Marboh, E.S., Kumar, A., Nath, V., 2019a. Effect of pollen grain sources on fruit set and retention in 'Shahi' litchi. Multilogic in Science 9(29), 152-156.

Lal, N., Gupta, A.K., Marboh, E.S., Kumar, A., Nath, V., 2019b. Effect of pollen grain sources on success of hybrids in 'Bedana' Litchi. International Journal of Bioresource and Stress Management 10(3), 241-245.
Lal, N., Kumar, A., Nath, V., 2020. Quantitative analysis of relationships between panicle size and fruit traits in litchi (Litchi chinensis Sonn.). International Journal of Bioresource and Stress Management 11(4), 381-386.

Lal, N., Sahu, N., Marboh, E.S., Gupta, A.K., Kumar, A., Nath, V., 2021a. Effect of Pollen Grain and Pollination Period on Fruit Set in Litchi (Litchi chinensis Sonn.). National Academy of Science \& Letters 44(5), 461-464.

Lal, N., Singh, A., Gupta, A.K., Marboh, E.S., Kumar, A., Nath, V., 2019c. Precocious flowering and dwarf NRCL-29-A new genetic stock of litchi (Litchi chinensis Sonn.). Chemical Science Reviews and Letters 8(32), 206-210.

Marboh, E.S., Gupta, A.K., Gyanesh, K., Singh, M. Singh, A., Nath, V., 2018. Genetic variability, heritability and genetic advance in litchi (Litchi chinensis). Indian Journal of Agricultural Sciences 88(10), 1510-1514.

Marboh, E.S., Gupta, A.K., Singh, M., Lal, N., Nath, V., 2019. Litchi: In: Peter, K.V. (Ed.), Origin and Biological Diversity of Horticultural Crops. Brillion Publishing, New Delhi, 107-137.

Mir, M.M., Sofi, A.A., Singh, D.B., Bhat, F.N., 2006. Correlation and path coefficient analysis in pomegranate (Punica granatum L.). Journal of Horticultural Science 1(2), 104-108.

Patel, R.K., Maiti, C.S., Deka, B.C., Verma, V.K., Deshmukh, N.A., Verma, M.R., 2015. Genetic variability, character association and path coefficient study in guava (Psidium guajava L.) for plant growth, floral and yield attributes. International Journal of Bio-resource and Stress Management 6(4), 457-466.

Rajan, S., Yadava, L.P., Kumar, R., Saxena, S.K., 2009. Genetic divergence in mango varieties and possible use in breeding. Indian Journal of Horticulture 66, 7-12.

Singh, A., Nath, V., 2012. Variability in fruit physicochemical characters of litchi (Litchi chinensis Sonn.): an index for selection of improved clones for processing and value addition. Indian Journal of Genetics and Plant Breeding 72(2), 143-147.

Srivastava, K., Sharma, D., Pandey, S.D., Anal, A.K.D., Nath, V., 2017. Dynamics of climate and pollinator species influencing litchi (Litchi chinensis) in India. Indian Journal of Agricultural Sciences 87(2), 266-269.

Srivastava, K.K., Verma, M.K., Ahmad, N., Razvi, S.M., Ahmad, S., 2014. Genetic diversity and divergence analysis in sweet cherry (Prunus avium L.). Indian Journal of Horticulture 71(2), 156-161.

Verma, R.K., Pandey, V.P., Solankey, S.S., Verma, R.B., 2014. Genetic variability, character association and diversity analysis in turmeric. Indian Journal of Horticulture 71, 367-372. 